\title{
Housing and an Aging Population: Implications for Architectural Education
}

\author{
Olufunto Ijatuyi, Errol Haarhoff, Alessandro Melis \\ The University of Auckland, New Zealand
}

\begin{abstract}
The question of aging population in the built environment is one of several societal realities in the world, and its connection with housing cannot be ignored. The indispensability of housing as one of man's basic needs makes it crucial to the concept of active aging in the built environment. This paper examines the place of architectural education within the context of housing for the aging population, and its role in fostering intergenerational linkage. The study examines the curricula of the Departments of Architecture in the University of Auckland, New Zealand, and the Federal University of Technology, Akure Nigeria, to identify the knowledge gaps affecting appropriate age-friendly housing design. The discovery of the absence of crucial course contents useful for modelling pedagogy and the comprehension of the dynamics of changing housing needs, both underscore the need to review the curricula. Where these courses exist, their applications are not evident. Acknowledging that tutelage cannot be completely exhausted in the design studio, the study recommends that the academic training of architecture students should embrace options that involve socio-economic and psychological concerns such as behavioral architecture, building economics and demography; this will facilitate intergenerational relationships and age-friendly designs.
\end{abstract}

Keyword: Aging Population, Architectural Education, Curriculum, and Housing.

\section{Introduction}

$\mathrm{T}$

he realization of a humane and responsive environment that must be improved and sustained is the aim of architectural education. To achieve this, architects are trained to understand the nature of societal problems (Olotuah and Adesiji 2005; Adedeji et al. 2012, 89). Furthermore, the purpose of Architectural education is to teach students the requisite values and skills for solving housing-related questions in the built environment. For this reason, greater emphasis is generally put on the architectural design module than other modules, because the design studio is the nucleus of architecture curriculum through which students are equipped with the knowledge and skills for modelling, re-ordering, and the articulation of the built environment (Olotuah and Adesiji 2005; Adedeji et al. 2012, 89). Glasser (2000, 252) maintained that the design studio actually developed from an apprenticeship system, and was considered as a knowledge workroom for the unravelling of skills and values. Therefore, the studio culture that sometimes inspires individual skills and predilections has birthed virtuosos in the world of architecture. According to Olotuah and Adesiji (2005) the curriculum of study in architecture makes professionals who are thoughtful of human aspirations and needs and have the required knowledge and skills to solve built environment problems. In reality, the virtuosity of architects is evident in the expressive and celebrated buildings in the world. However, the extent to which many of these illustrious designs are sensitive to human needs and aspirations remains questionable. Though the emphasis on design studio is imperative, there remains a question of how well contemporary design solutions meet the changing housing needs of the aging population. Questions cannot be appropriately identified and specified except the fundamental issues are identified (Turner 1977). Therefore, architectural education remains an underlying factor that determines the subsequent performance and output of the architects. For man, housing is an indispensable necessity, and the part the architect plays in the provision of appropriate housing is essential to the built environment.

While advocating market expansion for more services of the architect on account of increasing marginalization in the home-building industry, Friedman (2000) affirmed the need to redefine the scope of architectural education and practice to consider more social and economic concerns. The attitudes and skills currently being imparted in architecture schools must change to reflect the new requirements of the profession (Friedman 2000). One of these new requirements or needs is marked in the housing demands of the growing aging population. Suffice to note that the unparalleled aging of societies of nearly all nations indicates that the world is facing a critical demographic change (Malanowski, Cabrera, and Özcivelek 2008). In fact, in future decades, aging individuals will be the fastest growing sections of the populations of Organization for Economic Co-operation and Development Countries (Rosenberg and Everitt 2001). Furthermore, the United Nations has forecast 
that virtually one third of the world population (32.5\%) will be aged 65 or older in 2050 (Demirkan 2007, 33). This demographic transformation is the consequence of the combinations of decreasing fertility and increasing life expectancies in various places. A report prepared as a contribution to the World Assembly on Aging held in Madrid Spain in 2002, by the Population Division of the Department of Economic and Social Affairs of the United Nations, highlighted the salient features of the global trends in population aging as being unprecedented, pervasive, enduring, and having profound implications on human life. Obviously, housing is one of the areas where the impact of population aging is felt, and as the population of older people increases worldwide, the housing situations of this group of people remain critical across the world due to numerous issues which Edwards and Harding (2006) referred to as an interaction of questions such as age, health status, housing type and tenure. All these affect housing need, and their products are the mounting multiplicity of varying situations. As stated by Edwards and Harding (2006), this multiplicity involves choices or decisions that aging people are competent and disposed to make about their future housing needs.

Therefore, addressing the emerging housing challenges of an aging population in any society necessitates a well-managed strategy. Achieving this from the perspective of architectural design requires some knowledge and training through architectural education. This is important because the housing situations of aging individuals are diverse and challenging to address because housing needs encompass a complicated array of varying factors (Crisp et al. 2013). Since the importance and the profundity of study that is committed to housing differ from one architecture school to another (Olotuah and Ajenifujah 2009, 88), the curricula of architecture schools necessitate critical consideration to identify how well they are meeting housing needs (particularly that of the aging population), in order to be pertinent to a country's contemporary socio-economic conditions.

Therefore, this paper places emphasis on the role of architectural education in addressing the housing questions relating to the world's aging population. This is because architectural education involves the training of architects who are responsible for the design of housing for the aging population. For this reason, the paper sets out to consider the curricula of two purposively selected architecture schools in a more-developed country and a less developed country (New Zealand and Nigeria). These are purposively selected because they represent the groups of countries considered by the United Nations Population Division as being affected by the population aging trend (Martins 2010, 33-34), and the researchers are familiar with these places as well. The paper will then explore the curriculum of study in both architecture schools to see if there are crucial courses that are relevant and useful for training the students to prepare and equip them with the understanding of the dynamics of changing housing needs and age-friendly designs.

\section{Population Aging Trend}

When a section of a population experiences growth which is above a certain age (usually 65), this situation is termed population aging (Martin 2010,33). One of the definitions of population aging also considers it as the situation where there is a rise in the median age of a place due to factors such as declining fertility, falling birth rates, and rising life expectancy (Jackson 2011; United Nations 2007 cited in Lutz, Sanderson, and Scherbov 2008). Therefore, the cause of aging population trend is generally associated with increase in life expectancy and reduced fertility.

Fundamental to world-wide population aging is a progression recognized as the demographic transition in which mortality and fertility drop from upper to lower levels (United Nations DESA 2013). The trend in population aging is experienced by all the nations in the world; however it is more prevalent in the more-developed countries than in the less-developed countries (see Table 1). Its prevalence in the more-developed countries can be attributed to good environment, high living standards, and the advancement in medical technology. According to the figures in Table 1 , it is interesting to note that in the year 2000, the percentage of people aged 65 and above, in the moredeveloped countries is significantly higher than that in the less-developed countries $(14.4 \%$ and $5.0 \%$ respectively). However, the absolute number of older persons is greater in the less-developed countries (more-developed: 171.5 million; less-developed: 245.7 million), and this implies that the occurrence of aging is worldwide (Martin 2010, 34). 
Table 1. Population ages 65 and over (number in millions and per cent of total population)

\begin{tabular}{|c|c|c|c|c|c|c|}
\hline \multirow[b]{2}{*}{ Year } & \multirow{2}{*}{$\begin{array}{c}\text { World } \\
\text { Millions }\end{array}$} & \multirow[b]{2}{*}{$\%$} & \multicolumn{2}{|c|}{$\begin{array}{l}\text { More-developed } \\
\text { countries }\end{array}$} & \multicolumn{2}{|c|}{$\begin{array}{l}\text { Less-developed } \\
\text { countries }{ }^{b}\end{array}$} \\
\hline & & & Millions & $\%$ & Millions & $\%$ \\
\hline 1950 & 130.5 & 5.2 & 63.9 & 7.9 & 66.6 & 3.9 \\
\hline 2000 & 417.2 & 6.8 & 171.5 & 14.4 & 245.7 & 5.0 \\
\hline 2050 & 1486.9 & 16.2 & 334.2 & 26.2 & $1,152.7$ & 14.6 \\
\hline $\begin{array}{l}\text { a Mor } \\
\text { and } N \\
b \text { Less } \\
\text { the Ca }\end{array}$ & $\begin{array}{l}\text { loped cou } \\
\text { merica, as }\end{array}$ & $\begin{array}{l}\text { are de } \\
s \text { Aust }\end{array}$ & $\begin{array}{l}\text { ed by the } \\
\text { ia, Japan, a }\end{array}$ & $\begin{array}{l}\text { d Natio } \\
\text { Iew Zec }\end{array}$ & $\begin{array}{l}\text { as the co } \\
\text { ind. }\end{array}$ & ries of \\
\hline
\end{tabular}

Source: Data from United Nations Population Division, 2009, cited in Martin (2010, 34).

Evidently, the world is aging at a rapid rate, and by 2030, there will be 34 nations where more than $20 \%$ of the population will be over the age of 65 . Essentially, this has broad implications for the world's economic growth and immigration trends. Scared by the economic effect of the aging population trend, Petroff $(2014,1)$ declared through CNN Money, that "the world is greying at a break-neck pace and that's bad news for the global economy". Quoting Moody's Report written by Elena Duggar and Madhavi Bokil, Petroff $(2014,1)$ stated further that "by 2020, 13 countries will be "super-aged" - with more than $20 \%$ of the population over 65 ; that number will rise to 34 nations by 2030. Only three qualify now: Germany, Italy and Japan". Furthermore, over the next two decades, the economic growth of all regions in the world will be affected by the adverse effects of an unparalleled aging population trend. Yet, the effect of this trend is not limited to economic sector. The Population Division of the Department of Economic and Social Affairs of the United Nations prepared a report as a contribution to the World Assembly on Aging held in 2002. This report highlighted the salient features of the global trends in population aging as being unprecedented, pervasive, enduring, and having profound implications on human life. In other words, rapid aging will be more phenomenal in the $21^{\text {st }}$ century, and everybody in all countries including all aspects of human life will be affected at different stages; in addition, young populations that our forefathers knew will not be seen again. This sounds predictive, but it is essentially a clarion call for a strong devotion to careful planning and considerations in all sectors of which housing is inclusive, since this impending situation affects housing socially, economically, physically, and even numerically.

\section{Housing and Population Aging: The Nigeria Context}

Even though housing is a sine qua non for human existence, the rate of provision of adequate housing stock in Nigeria has really lagged behind the rate of population growth, leading to the formation of slums, squatter settlements, high rent and a preponderance of the enormous share of urban dwellers (Olotuah 2009, 35-36; Olotuah and Ajenifujah 2009, 96). Low-income households and the poor who are over $70 \%$ of the urban population do not have access to affordable housing; this makes the housing problem more critical in the cities. Going by forecast, Nigeria will need between 12.5 and 14 million dwelling units of numerous types by the end of the year 2015, and to 
meet this demand, Nigeria has to build at the rate of 1.2 million houses annually (Mohammed 2015). New housing developments must meet the needs of the aging population because very many dwelling units are substandard, let alone aged-friendly.

By 2050, almost 8 out of 10 older people will live in less developed regions of the world because the older population in these areas is growing faster than in the more developed regions (United Nations DESA, 2013). Being the most populous country and with the highest population of older people in Africa (Kinsella and Velkoff, cited in Ajomale 2007), the case of Nigeria is significant. By projection, the population of Nigerians who are 60 years and over will make up 6 percent and 9.9 percent of the total population in 2025 and 2050 respectively (see Table 2).

Table 2: Population of Nigerians who are 60+ compared to West Africa and Africa

\begin{tabular}{|l|l|l|l|l|l|l|}
\hline & \multicolumn{3}{|l|}{ Population 60+ (per cent) } & \multicolumn{2}{l|}{ Population 60+ (millions) } \\
\hline Year & 2005 & 2025 & 2050 & 2005 & 2025 & 2050 \\
\hline Africa & 5.2 & 6.4 & 10.0 & 47.4 & 85.8 & 192.9 \\
\hline West Africa & 4.7 & 5.5 & 9.0 & 12.0 & 21.8 & 51.6 \\
\hline Nigeria & 4.9 & 6.0 & 9.9 & 6.4 & 11.5 & 25.5 \\
\hline
\end{tabular}

Source: UN population division, cited in Ajomale (2007)

With over 250 multi-ethnic groups, Nigeria is culturally diverse. The major ethnic groups are the Hausa (North), Yoruba (South-West) and the Igbo (South-East). The perceptions of care for older persons among these ethnic groups are related, and they share some similar cultural traits (Ajomale 2007). Across Africa, filial responsibility of employed adults towards their parents is to some extent, ethically preserved and expressed in care and support. Because older people receive care from their family members who have been the mainstay of care and provision (Aboderin 2006, 6; Aboderin 2004, S128-S129), residential care homes are not preferred in Nigeria. The very few available care homes are mostly owned by religious institutions having poor standards that do not meet the needs of the older individuals (Ajomale 2007). The value of a house is defined by the degree to which it satisfies or aggravates the needs of its users; therefore, meeting people's housing needs is central to appraising housing quality (Turner 1972, cited in Olotuah 2009). Unfortunately, apart from generally poor housing quality, the amount of care provided by the relations of older people in recent times is gradually abating. This is traceable to the mounting problem of unemployment, rural-urban migration, and gradual fragmentation of the extended family, among others. With the critical condition of unemployment, most adult children who are saddled with the cultural and filial responsibility of taking care of their elderly parents constantly live on survival lane and are not able to meet this obligation (Aboderin 2004, S128; Togonu-Bickersteth and Akinyemi 2014, 365-368). Therefore the issue of poor housing for the aging population is aggravated by dwindling care and support from nuclear or extended family members, as well as from the government that has apparently reneged from its constitutional welfare and care role for the citizenry, and has no concrete plan or institutional framework (Mudiare 2013, 79) for meeting the housing needs of the aging population.

\section{Housing and Population Aging: The New Zealand Context}

Similar situation of diversity in population thrives in New Zealand, and this diversity will remain (Saville-Smith 2010). The aging population of New Zealand is growing as in other nations. This swiftly growing older population is characterized by heterogeneity; and housing this cohort necessitates diverse housing types as a way out (Grant 2006). For instance, among the Maoris, Papakainga (which means nurturing a place to return to) is a system of housing development that takes place on collectively-owned or multiply-owned ancestral land (Whangarei District Council 2015). The knowledge people's housing needs helps in inspiring appropriate approach to addressing them. 
The population of New Zealand will reach 4.8 million people in 2021, and this growth is not predicted to be homogeneously distributed in all the regions of the country (Statistics New Zealand 2000). Saville-Smith, et al. $(2009,28)$ noted in a report which was prepared for the Centre for Housing Research in Aoteaoroa, New Zealand (CHRANZ), that "New Zealand's population has been aging as the baby-boomers age. The impact on New Zealand society of that bulge of babyboomers was first felt in the demand for housing, maternity services and schools experienced in the 1960s to 1970s. Those cohorts are now going to have needs in the future to which New Zealand as a whole will have to respond". They also stressed that the age profiles of different ethnic groups (Asian, European, Maori, and pacific people) make it a bit complex, although this not unique to New Zealand. Furthermore, by 2051, one in every four of all New Zealanders (25\%) will be sixtyfive years and over, and half of the population will be above forty-six years (Statistics New Zealand 2000). These figures reveal the advent of older individuals in the society. Bearing in mind that housing is a determinant of well-being the need for appropriate age-friendly housing for these future trends calls for urgent attention.

An inclusive scheme named Positive Aging Strategy (PAS) was developed by the Ministry of Social Development of New Zealand in 2001. The goal of this framework is to cater for the broad needs of the aging population in order to ensure a society where "people can age positively, where older people are valued, and where they are recognized as an integral part of families and communities" (Ministry of Social Development 2001). Positive aging is considered a life time process which begins at birth. It touches cursorily on intergenerational linkage by reflecting how younger generation view aging in general. It predominantly sketches central policy principles for positive aging and sets out model objectives and key actions in ten areas of Income, health, housing, transport, aging in place, cultural diversity, rural communities, attitudes, employment, and opportunities (New Zealand Positive Aging Strategy, Ministry of Social Development 2001). This framework has been helpful to the vision of the country; however, argument against the PAS emphasizes that it favors a western outlook without sufficiently representing the interest of the people by defining positive aging from the perspectives of different cultures and ethnicities in New Zealand (Li 2011; Edwards 2010). Apart from this, though two of the goals of the PAS are to ensure "affordable and appropriate housing options for older people," and that "older people feel safe and secure and can age in place" (Hutchison, Morrison, and Mikhailovich 2006, 14), yet, fulfilling these goals remains a challenge. It is therefore important to explore the place of architectural education in meeting these goals in other to ensure optimum relationship between older individuals, their housing situations intergenerational linkage.

Furthermore, hands-on efforts to resolve the housing issues of the aging population in New Zealand are expressed in developments such as rest homes and retirement villages. Yet, the diverse nature of the housing needs of old people remains a challenge to design. In fact, Saville-Smith et al. (2009) decried this housing situation and outlined three scenarios that should be expected: firstly, the "business as usual" scenario, whereby there are very little, slow and fragmented responses to societal aging process; secondly, the "integrated response" scenario during which of older people's housing needs are reprioritized in order to promote independence and active living; thirdly, the "fragmented innovations" scenario, which comprises housing innovation that are driven by housing market but are without coherent framework or approach which responds to an aging society. From the foregoing, it implies that it is necessary to provide an integrated response in the form of a coherent framework that best meets the needs of the aging population.

\section{Architectural Education and the Dynamics of Constructed.}

The content of what architecture students imbibe in formal academic training is essential to the design solutions which they deliver throughout professional practice. Demirbas and Demirkan (2003, 437) stated that the curriculum in architectural education should be designed to facilitate, support, and develop students' learning. Hence, the common aim of architecture schools is to enhance the profession of architecture particularly through teaching and the generation of new knowledge (Olotuah 2009). Many buildings which were designed by trained architects several years ago are gradually failing in their functionalities and services to older individuals. This depicts a 
design gap betrayed by the continuous transformation of the built environment. While people's interactions change with the indoor and outdoor environment as they age, there is the need for homes that meet their special and varying perceptions and needs. Therefore, does architectural education really contain or permit studies in behavioral architecture, psychology, sociology and the likes, to equip the student with the knowledge of the vicissitudes of human dispositions? It is pertinent to point out that an illusion of impression is merely created if buildings are not modifiable for people's use as they change, or if such buildings were not universally designed for agefriendliness. Before now, buildings were exclusive creations (Beadle, et al. 2008, 1126; Eguchi et al. 2011, 73) and were erroneously designed and constructed as bespoke static structures within the built environment. This is a direct consequence of what architecture students study and acquire through formal (academic) and informal (practice) spheres of influence. Formal erudition is received through architectural education, while informal knowledge is acquired through architectural practice.

Gibb et al. (cited in Beadle et al. 2008, 1126) acknowledged that many existing buildings are rigid creations that were designed to suit specific purposes. This position was corroborated by Nugent et al. (2011) who attested that buildings have been constructed to meet specific needs such as comfort, income estimate and function; these needs dwell on the momentary situations, and regularly necessitate modification when such situations or needs change. However, the continuous transformation of the environment (Y1lmaz 2006; Beadle et al. 2008, 1125; Nugent et al. 2011) built or unbuilt - seems to have recently necessitated the perception of buildings no longer as static structures, but as one of man's dynamic and interactive products. Buildings are dynamic because they experience progressive and constant change over time; and their interactive nature is expressed in their ability to be influenced by the activities of man. Kendall and Ando (2005) acknowledged that the understanding of the phenomenon of change is very important, because the built environment is in continuous transformation, and this is the result of an unending design process whereby components of the human environment such as buildings and neighborhoods transform section-by-section. Realizing the dynamism of buildings, built environment experts have awaken to the pressing need to ensure the compliance of buildings with the human environment. For nearly three decades this necessity has been discussed within several relevant themes in many academic fora. The need to efficiently relate and adapt with the burgeoning and dynamic human environment has brought various concepts such as adaptable design, barrier-free and universal designs, and flexible buildings to the foreground of the built environment. These are not covered in this study.

\section{Architectural Education in Nigeria: a Brief Background.}

The first school of architecture in Nigeria was established in 1952 in Ibadan. It was called the Nigerian College of Arts, Science and Technology. This school was relocated to Zaria in 1955 (Adegbile 2012); it graduated its first set of students in 1961, and was later upgraded from a College to a University (Ahmadu Bello University, Zaria) in 1962 (Olotuah and Ajenifujah 2009, 93-94). The curriculum in this first architecture school in Zaria was instituted by the British. Consequently, students who graduated in 1961 were awarded diploma in architecture, and were exempted from parts I and II of RIBA professional examinations. Upon upgrading to a University, architecture curriculum was restructured and graduates were awarded Bachelor of Architecture degree, which shared similarity and connection with the previous Diploma. Connection with RIBA was maintained until 1968, after which a two-tier degrees of Bachelor of Science (B.Sc.) and Master of Science (M.Sc.) in architecture was introduced in 1969 (Olotuah and Ajenifujah 2009, 93; Olotuah and Adesiji 2005; Adegbile 2012). Till date, schools of architecture in Nigeria have predominantly designed their curricula after the British and American models of architectural education; nevertheless, changes have been made to the original programmes to reflect Nigerian societal needs and aspirations (Olotuah and Ajenifujah 2009, 93). The Nigerian colonial experience was not limited to architecture schools alone, but cuts through the whole education system in Nigeria (Uji 2006 cited in Olotuah 2006). 


\section{The Department of Architecture, Federal University of Technology, Akure Nigeria: Overview of Courses}

The Department of Architecture in the Federal University was established in 1989 (this was seven years after the University was founded in 1982). According to the requirements of the country, the National Universities Commission (NUC) specifies minimum standards which regulate the curriculum design in all the universities offering architecture as a course of study in Nigeria. Courses are therefore, categorized into seven modules; these are: Architectural Design, Arts and Drawing, Historical and Theoretical Studies, Building Systems Technology, Humanities and Social Studies, Environmental Control Systems and Physical Sciences (Olotuah and Ajenifujah 2009, 9394; Olotuah and Adesiji 2005). At the Department of Architecture, Federal University of Technology, Akure Nigeria, these modules are articulated in taught courses. Thus, schools of architecture in Nigeria have numerous and voluminous course titles which can be chosen from these modules.

Being the nucleus of architecture, housing lessons are entrenched into architectural design module, and are a chief chunk of it. Housing also forms a part of the humanities and social studies modules (Olotuah and Ajenifujah 2009, 94) at the Department of Architecture in the Federal University of Technology, Akure (hereinafter Arch-FUTA). With reference to Tables 3 and 4, without doubt, Arch-FUTA enjoys a vast variety of courses. However, though housing issues are taught in the design studio and in other related theoretical courses such as Humanities and Social Studies modules (Man and His Environment, Behavioral Architecture, Building Law), the subtle vicissitudes of housing needs are not given a comprehensive and in-depth study. Students are continually inclined to dated architectural questions, and they seem to be uninformed about the dynamics of the varying housing needs of the society. This is traceable to, and marked in the course contents and knowledge materials currently in use. Some of these are reference books that specify data for spatial requirements in site planning and building design for study and practice, though they are handbooks which are justifiably essential for students and architects alike.

Some of the course contents and reference materials merely define standards that are limited in scope, and cannot be applied as a one-size-fits-all answer to the housing questions of aging societies. Going by the contemporary housing and environmental questions facing humanity, among which are the changing, unpredictable housing requirements for the aging population, some of the issues addressed in these courses and reference materials cannot appropriately address changing contemporary housing needs of older people living with various frailties. The consequences find expression in the shortfall of the knowledge conveyed to students who are expected to design buildings that pertinently meet people's requirements. Therefore, it is imperative for architecteducators to be sensitive to new housing challenges, and get engaged in the quest for pertinent answers to these housing questions in order to appropriately instruct their students.

At Arch-FUTA, architecture students devote five academic sessions (ten semesters) to attaining bachelor's degree, and one and a half academic sessions (three semesters) to master's degree. The total is nearly seven years. Courses in the first year of undergraduate studies are predominantly introductory, and twenty courses totaling 43 units (215 points) are taken. Students take introductory courses in Architecture and Planning, and external courses in Computer Science, Engineering, Physics, English, and Library. Though some students consider these courses as superfluous, however, the goal is to equip them with relevant knowledge from these courses in order to creatively and critically apply such knowledge to design solutions where necessary. Such external courses get them prepared for creative and critical thinking required for further learning in school and practice after school.

In the second year, eighteen courses of 48 units (225 points) are studied. Students take Architectural Design, Theory of Structures, Architectural History, Graphics, Basic Construction Methods, Building Components and Materials, and Land Surveying. Courses in Computer Programming, Wood Work, and Agriculture are studied as well. In addition, courses involving humanities and social sciences which are studied at this level are Principles of Economics and two courses in General Studies (Man and his Environment, Nigerian History and Culture). These are 
university courses which some students also find hard to reconcile with their major disciplines because the outlines of these external courses are not well designed for appropriate applications in various disciplines. However, if well-structured and designed, they are pertinent to the issues surrounding aging population, intergenerational relationship and other social phenomena in the built environment.

Year Three courses include Architectural Design, Building Structures, Visual Design, Building Components Services and Methods, Building Economics, Environmental Control (Climatology), History of Western Architecture, Urban Renewal Process, Basic Elements of Planning, Principles of Measurement and Description (Quantity Surveying), Urban Design Theory, and Village Survey. All these make a total of 205 points (41 units). At this level, most of the courses are strongly related to the discipline of architecture.

All Year Four students in the university undergo Industrial Training or Attachment throughout the second semester. During this period, students work in industries for six months so as to be able to situate the knowledge gained in school into practical, real-life settings (on the field) while learning new things. Courses for the first semester are Architectural Design, Landscape Theory and Design, Construction Detailing, Modern Movement in Architecture, Environmental Control II (Lighting \& Illumination), Building Structures (Steel/Timber) Design, Behavioral Architecture, and Construction Economics. This makes a total of 35 units (175 points). Behavioral architecture is a two-unit (10 points) course devoted to the use of space within the context of behavior, culture, attitudes, or dispositions. As a course (connected to humanities and social sciences), it has relevant information that is useful in furnishing architecture students with the requisite knowledge to address human behavioral tendencies within spaces. Thus, knowing and applying studies in subjective or behavioral tendencies within design conceptions can help to better understand how to meet the housing needs of the aging population. However, this course mainly deals with topics such as defensible space, environmental, human or behavioral determinism, etc. If it is well designed, it could be a very useful tool in tutoring students on questions relating to the aging society.

In the final year (year five) of the bachelor's degree, the following courses are studied: Advanced Design Studio, Construction Detailing, Comparative Studies of Built Form, Modern Movements in Architecture (history), Interior Design, Environmental Control (Acoustics and Noise Control), Housing Seminar, Independent Research Project, Rural Development and Planning, Building Law, and Tourism and Recreation Planning. The total point for the courses in the fifth year is 185 . Therefore the aggregate point for all the five years is 1005 .

The master's program follows on from the Bachelor's program. To apply for registration as a professional architect, the master's degree qualification is required. Thus, to the master's degree (M.Tech), three semesters are devoted. The first semester is devoted to taught-courses, the second semester is devoted to both taught-courses and the preliminary part of the thesis, and the substantial part of the last semester (Year 2) is devoted to thesis, though two other taught courses are involved (thesis writing starts from the second semester). At the master's level, courses taken are Advanced Architectural Design, Arbitration and Awards, Specification Writing, Design Economics and Cost Planning, Research Methodology, Professional Practice and Procedure I and II, Applied Climatology, Advanced Urban Design, Environmental Impact Assessment, Construction Management, Design Seminar, Current Issues in Practice, Advanced Design Studio: Thesis.

The copiousness of knowledge in the field of housing in Nigeria has not always influenced good and proper implementation. While the aforementioned plethora of courses in Arch-FUTA show that students are imparted with great wealth of knowledge, it is important to make sure that such knowledge meets contemporary needs. Therefore, from the inclusive nature of the curriculum at Arch-FUTA, it can be concluded that what needs to be done is a review and update of the curriculum so as to reflect current and future housing questions relating to the aging population, and ways of resolving them. 


\section{Architectural education in New Zealand: a brief background}

Going by the account of McEwan (1999, 1-8), Canterbury College used to have a School of Fine Art under which architecture was taught for several years. In 1914, Samuel Hurst Seager - an enthusiast of architectural education, a distinguished local architect, and a director of the School of Fine Art - introduced a three-year Diploma course in Architecture in the College. Though the First World War took its toll on the development at Canterbury College, it further experienced enrolment setback when the first architecture school in the old Auckland University College was founded in 1917. In 1924, a Chair in Architecture that was funded by the New Zealand Institute of Architects (NZIA) was instituted. This brought about the arrival of Professor Cyril Roy Knight (the first Professor of Architecture in New Zealand), a preparation of a novel school curriculum, and the inception of a full-time study in 1925. Furthermore, as a quintessence of a broad knowledge in architectural education and practices, with extensive travels and overseas visits, Knight, who was an experienced Architect and Town Planner, was an authority in New Zealand architectural education as well. As a result, his thirty-three years' service in Auckland College was impactful.

During this period, the curriculum at the School of Architecture was shaped by foreign influences because architect-educators and practicing architects had overseas training and experiences. Consequently, the influence of Knight's presence, the support of volunteer mentors such as Roy Lippincott and Horace Massey (who acted for him during his important visits abroad), and the efforts of A.M. Chisohm (who was an architect-educator) formed a blend of American, British and French pedagogic practices, which was seen in the curriculum of degree, professional and diploma courses that were established in 1926. For several years, the Beaux-Arts design principles were very prominent and influential, and their espousal was prevalent in both pedagogic and professional endeavors. The qualification of graduates was recognized all over the world after the School received international recognition by the Royal Institute of British Architects in 1931 (Creative Arts and Industries 2016).

\section{The School of Architecture and Planning, University of Auckland New Zealand: Overview of Courses.}

Actually, housing study is inseparable from the design studio. Thus, the syllabus in most architecture schools identifies the position of housing in the growth and expansion of the built environment. Though housing is entrenched in the design studio and is a central aspect of it, topics that are related to age-friendly designs are not noticeable in the course outlines at the School of Architecture and Planning, University of Auckland New Zealand (hereinafter Arch-CAI). The curriculum does not really show emphasis on an inclusive and exhaustive study of age-friendly related subjects. At Arch-CAI, architecture students devote three academic sessions (six semesters) to attaining bachelor's degree, and two academic sessions (three semesters) to master's degree. The total point of all the courses is 360 for the three years of bachelor's degree (120 points for each year). For the master's degree, the total point of the courses is 240 . Obviously, the number of years spent in Arch-CAI is less than that of Arch-FUTA; however, this does not matter because the number of years for obtaining degrees depends on the goals and policies of different countries and their institutions.

First year courses in Arch-CAI are Design Studio (first and second semester), Architectural Media, Modern Architecture and Urbanism, Architecture and Sustainability, Design Technology, and any approved course in General Education. The only course which is not related to architecture is the course in General Education, and it is $25 \%$ of the total points. Courses taken in the second year are Design Studio (first and second semester), Architectural Media, Contemporary Architecture and Urbanism, Design Technology, Introduction to Architectural Theory, and Environmental Design. In the third year, the courses are Design studio (first and second semester), Oceanic Architecture and Urbanism, Environmental Design, Pre-modern Architecture and Urbanism, Design Technology, Design as Research, and one other elective approved by the department. The implication of this is that in the entire three years, students may not receive sufficient tutelage in subjects dedicated to humanities and social studies such as behavioral architecture - apart from 
history-related courses - which will enlarge their horizon and capability in meeting contemporary housing needs. Nonetheless, one of the things that are highly laudable about the design studio in Arch-CAI is that designs are highly practically-driven. This is ensured through detailed analysis, site visits, and the making of both visual and physical three dimensional models, thereby making the designs close to reality. In fact, sometimes, students' designs move from paper to site. However, the subjects related to behavioral architecture in the curriculum needs to be included in the curriculum because of the inseparable concerns of housing and population aging in the $21^{\text {st }}$ century.

At the master's level in Arch-CAI, four different programs are offered. These are: Master of Architecture [(Professional) (MArch (Prof)], Master of Architecture (MArch), Master of Architecture (MArch) - in Sustainable Design, and Master of Heritage Conservation (MHerCons). Of these four programs, the Master of Architecture [MArch (Prof)] is the only qualification that is a prerequisite to applying for registration as a professional architect. For the MArch (Prof), the students take the following courses over two sessions (four semesters): Advanced Design (first and second semester) and Professional Studies (first and second semester). Also, students are required to take any two courses in any of the following special topic areas: special topics in History, Theory and Criticism (Building the case, Heritage Conservation, Looking Again, Surfaces in situ), special topics in Sustainable Design (Designing with Resilience Thinking, Climate Sensitive Design for urban mutations), special topics in Urban Design (Cities within the City, Urban Public Spaces in the Contemporary City, Theory and Practice, and Dissenting Images and unbuilt urban projects), special topics in Materials and Fabrication (Timber Workshop Project, Timber Technology, Disruptive Technologies, Advanced Sound and Buildings, Light Scale II: AR Installation and Research Project) and Thesis (first and second semester).

Thus, the design studio seems to focus more on architectural questions about building forms in relation to contemporary sustainable design issues. This is conspicuous in the course contents and the students' submission during the juried exhibition at the end of the semester. A lot of commendable effort is expressed in the students' work but there needs to be an integration of adequate age-friendly subjects into relevant housing courses apart from the design studio. Otherwise, students may graduate with little or no knowledge in these important courses, and as a result, this knowledge gap remains and is transferred into architectural practice. Tables 3 and 4 itemize and compare the courses in both schools of architecture.

Table 3: Arch-FUTA and Arch-CAI: Comparison of Courses, Points and Years.

\begin{tabular}{|l|c|c|}
\hline & Arch-FUTA & Arch-CAI \\
\hline Total number of courses taken for Bachelor's degree & 77 & 23 \\
\hline Total number of courses taken for master's degree & 14 & 8 \\
\hline Total points for Bachelor's degree & 1005 & 360 \\
\hline Total points for master's degree & 285 & 240 \\
\hline Total number of years for Bachelor's degree & 5 & 3 \\
\hline Total number of years for master's degree & 1.5 & 2 \\
\hline $\begin{array}{l}\text { Are there courses devoted to humanities and social studies such } \\
\text { as behavioral architecture, building economics? }\end{array}$ & Yes & $\begin{array}{l}\text { No, except courses in } \\
\text { Architectural History. }\end{array}$ \\
\hline
\end{tabular}

Source: researchers' analysis of courses from Arch-FUTA and Arch-CAI

Table 4: List of courses at Arch-FUTA and Arch-CAI

\begin{tabular}{|l|ll|}
\hline \multicolumn{1}{|c}{ Arch-FUTA (Year 1) } & \multicolumn{1}{c|}{ Arch-CAI (Year 1) } & Point \\
\hline - Graphic Communication I and II & - Design I and 2 & \\
- Freehand Sketching I and II & $\bullet$ Architectural Media I \\
- Art and Architectural Appreciation & - Modern Architecture and Urbanism \\
- Nature of Environmental Science & $\bullet$ Architecture and Sustainability \\
- Introduction to Architecture & - Design Technology I & 120 \\
- Engineering Drawing & - General Education course & \\
- Workshop Practice & & \\
- Elementary Mathematics I and II & & \\
\hline
\end{tabular}


- General Physics I and II

- General Physics (Laboratory) I and II

- Use of English

- Introductory Computer Science

- Information Retrieval

- Logic and Philosophy

215

Arch-FUTA (Year 2) Point

- Architectural Design I and II

- Architectural Graphics I and II

- Groundwork of Architectural History

- Basic Construction Method

- Building Components And Materials

- Theory of Structures I and II

- Land Surveying I and II

- Computer Programming I

- Workshop Practice (Crafts)

- General Agriculture (Theory and practical)

- Man and His Environment

- Principles of Economics

- Nigerian History \& Culture

225

Arch-FUTA (Year 3) Point

- Architectural Design III and IV

- Visual Design Workshop

- Building Components And Methods

- Building Components and Services

- Building Structures (R.C. Designs)

- History of Western Architecture I

- Village Survey

- Environmental Control: Climate

- History of Western Architecture

- Urban Renewal Process

- Building Economics

- Basic Elements of Planning

- Urban Design Theory

- Principles Of Measurement and Description

$$
\text { Arch-FUTA (Year 4) }
$$

Point

- Design 5 and 6

- Oceanic Architecture and Urbanism

- Pre-modern Architecture and Urbanism

- Environmental Design II

- Design Technology III

- Any of the following courses: Life Drawing, Measured Drawing, Freehand Drawing, and Introduction to Photography

- Design as Research

- Architectural Design V

- Landscape Theory and Design

- Construction Detailing

- Modern Movement in Architecture

- Environmental Control (Lighting \& Illumination)

- Building Structures (Steel/Timber Design)

- Behavioral Architecture

- Construction Economics 

Arch-FUTA (Year 5)

- Advanced Design Studio I and II

- Construction Detailing II

- Comparative Studies Of Built Form

- Modern Movements in Architecture

- Interior Design

- Environmental Control III (Acoustics And Noise Control)

- Rural Development and Planning

- Building Law

- Tourism And Recreation Planning

- Housing Seminar

- Independent Research Project I and II Arch-FUTA [Year 7 (Masters)]

- Advanced architectural design (life project)

- Specification writing

- Research Methodology Point Arch-CAI [Year 7 ( Masters)]

- Advanced Design (first and second semester)

- Professional Studies (first and second semester)

- Special topics in History, Theory and Criticism (Building the case, Heritage Conservation, Looking Again, Surfaces in situ).

- Professional Practise and Procedure I and II

- Advanced Urban Design

- Environmental Impact Assessment

- Construction Management

- Arbitration and Awards

- Design Economics and Cost Planning

- Current issues in practice

- Design Seminar

- Advanced Design Studio: Thesis 265
- Special topics in Sustainable Design (Designing with Resilience Thinking, Climate Sensitive Design for urban mutations),

- Special topics in Urban Design (Cities within the City, Urban Public Spaces in the Contemporary City, Theory and Practice, and Dissenting Images and unbuilt urban projects),

- Special topic in Materials and Fabrication (Timber Workshop Project, Timber Technology, Disruptive Technologies, Advanced Sound and Buildings, Light Scale II: AR Installation and Research Project).

- Thesis (first and second semester).

Courses where age-friendly topics and aging population issues can be taught

Courses that are strongly related to humanities and social studies

Source: http://arc.futa.edu.ng/courselist.php; and http://www.creative.auckland.ac.nz/en/for/current-students/cs-course-planning-andenrolment.html\#par_contentblock_2_0 


\section{The place of architectural education in housing for the aging population and intergenerational relationship}

Architects should be schooled in subjects in behavioral architecture, architectural psychology, demographics, building economics, and related subjects. As a result, they can be able to apply their knowledge to real life situations, so that users, developers, and the housing industry at large will find their services beneficial and appropriate. Through proper architectural education, students are able to develop knowledge and aptitudes which are essential to recognizing architectural function, purpose, and meaning, and convert them into suitable design settings. While getting imparted with cultural values, they gain an expansion of the skyline of their world-view as well. The inability of architects to locate housing questions and position them into appropriate viewpoint is, to some extent, a consequence of insufficient architectural knowledge they received on housing issues (Olotuah and Ajenifujah 2009, 87). Therefore, observed gaps in knowledge can be linked to their curriculum of study during training.

The impact of architectural education on intergenerational relationship in this regard cannot be neglected. One of the avenues to foster intergenerational relationship is by imparting the knowledge of age-friendly designs to students. This is because age-friendly design approach is intergenerational in concept and its approach encompasses all age groups. Designing for all age-groups is therefore a way of creating intergenerational design which in turn fosters more knowledge in intergenerational relationship. While the world continues to grapple with demographic vicissitudes, the absence of the aforementioned essential courses in the curriculum only exacerbates and threatens the positive social impact of intergenerational relationship. Therefore, the degree to which the content of a course in behavioral architecture and the design studio promote the design for intergenerational relationship has significant implications for the practice of architecture. This is expressed in various design solutions and housing for the aging population. Intergeneration-focused approaches can be put in courses and can help to improve the effectiveness of an elderly-friendly housing intervention. This is the goal of universal design and is related to the pursuit of the concept of active aging which the World Health Organization is relentlessly promoting (WHO 2002), and this is clearly spelt out in the WHO guide for age-friendly housing (WHO 2007).

\section{Conclusion}

This paper has identified and placed emphasis on architectural education as an essential way of training and preparing architects in areas that are pertinent to housing questions which are related to the aging population, and which they may encounter in professional practice. The paper studies the curricula of the Departments of Architecture in the University of Auckland, New Zealand and the Federal University of Technology, Akure Nigeria and identifies the absence of crucial course contents useful for understanding the dynamics of changing housing needs. It is startling that attention is on several other means of ensuring appropriate housing for the aging population while the place of architectural education in the training of the architect in this regard is, perhaps, inadvertently neglected. The paper underscores the need to review these curricula.

A limitation of this paper is that it does not intend to propose a new curriculum that addresses the dearth of academic training of the students of architecture concerning the housing needs of the aging population. Rather, it advocates for the inclusion of relevant subjects or courses to the current curricula in these schools. Another limitation is that the paper focuses on just two schools of architecture. However, a look at the curricula of some top schools of architecture in Massachusetts Institute of Technology (MIT), University College London, Bartlett School of Architecture, Delft University of Technology, University of California, Berkeley (UCB), Harvard University, National University of Singapore (NUS), ETH Zurich, Tsinghua University, University of Cambridge, and The University of Tokyo, shows similar trend that has been outlined in the paper.

In the quest for quality in design, the design studio affords architecture students a great occasion to associate and blend different information and knowledge which they acquire. However, 
the acquisition of design knowledge should not be limited to the design studio. To develop and propose design solutions for housing questions like the aging population, students must be equipped with the knowledge of subject areas related to intergenerational relationship and age-friendly designs. When students are furnished with relevant knowledge related to contemporary issues, they can be sensitive enough to the needs of users, and be endued with the information and ability needed to view housing questions in a holistic and analytic way. Architects in practice can also learn the fundamentals of studies in humanities and social sciences at any stage in their professional careers, but it is better for them to be exposed to these basics during their training in school. Exposure to foundational courses in humanities within and outside the confines of architecture can help architects to envision their designs through the eyes of the users.

\section{REFERENCES}

Aboderin, Isabella. 2006. Intergenerational Support and Old Age in Africa. New Brunswick, New Jersey: Transaction Publishers.

Aboderin, Isabella. 2004. "Decline in Material Family Support for Older People in Urban Ghana, Africa: Understanding Processes and Causes of Change." The Journals of Gerontology Series B: Psychological Sciences and Social Sciences 59(3): S128-S137. doi: 10.1093/geronb/59.3.S128.

Creative Arts and Industries (CAI). 2016. About the School of Architecture and Planning. Accessed September 10, 2016. http://www.creative.auckland.ac.nz/en/about/our-faculty/schoolsprogrammes-and-centres/architecture-and-planning/about-the-school-of-architecture-andplanning.html.

Adedeji, Yomi M. D., Abraham A. Taiwo, Olukayode A. Olotuah, and Gabriel Fadairo. 2012. "Architectural Education and Sustainable Human Habitat in Nigeria." In Sustainability Today, edited by C.A. Brebbia, 89-100. Southampton UK: WIT Press.

Adegbile, Michael. 2012. "Nigerian Architectural Education in a Sustainable Age." Paper presented at Sustainable Futures: Architecture and Urbanism in the Global South Kampala, Uganda, June 27-30, 2012. http://sfc2012.org/adegbile_2.pdf.

Ajomale, Olayinka. 2007. "Country Report: Aging in Nigeria - Current State, Social and Economic Implications." Summer Newsletter of the Research Committee on Sociology of Aging of the International Sociological Association (ISA). Oxford Institute of Aging.

Beadle, Katy, Alistair Gibb, Simon Austin, Almudena Fuster, and Peter Madden. 2008. "Adaptable Futures: Sustainable Aspects of Adaptable Buildings." Paper presented at the TwentyFourth Annual Conference of ARCOM (Association of Researchers in Construction Management), September 1-3, 2008. http://www.arcom.ac.uk/-docs/proceedings/ar20081125-1134_Beadle_et_al.pdf

Eguchi, Toru, Robert Schmidt III, Andrew R.J. Dainty, Simon A. Austin, and Alistair G.F. Gibb. 2011. "The Cultivation of Adaptability in Japan." Open House International 36(1): 73-85. https://dspace.lboro.ac.uk/2134/8468.

Demirbaş, Osman O., and Halime Demirkan. 2003. "Focus on Architectural Design Process Through Learning Styles." 2003. Design Studies 24(5): 437-456. doi:10.1016/S0142694X(03)00013-9

Demirkan, Halime. 2007. "Housing For the Aging Population." European review of aging and physical activity 4(1): 33-38. doi:10.1007/s11556-007-0016-z

United Nations, Department of Economic and Social Affairs, Population Division (DESA). 2013. World Population Aging 2013. ST/ESA/SER.A/348. New York, USA: United Nations.

Edwards, Margaret, and Ed Harding. 2006. Building Our Futures: Meeting the housing needs of an aging population. London, UK: International Longevity Centre.

Edward, Hall. 1966. "The Hidden Dimension." New York: Doubleday, Garden City. 103-124.

Edwards, William John Werahiko. 2010. "Taupaenui: Maori Positive Aging." PhD diss., Massey University.

Friedman, Avi. 2010. "Rethinking Housing Education in Architecture Schools." International Journal of Architectural Research ArchNet-IJAR 4(2): 54-60. 
Glasser, David Evan. 2000. "Reflections on Architectural Education." Journal of Architectural Education (53)4: 250-252.

Grant, Bevan C. 2006. "Retirement Villages: An Alternative Form of Housing on an Aging Landscape." Social Policy Journal of New Zealand 27(March): 100-113.

Hutchison, Terese, Paul Morrison, and Katja Mikhailovich. 2006. "A Review of the Literature on Active Aging." Canberra: Healthpact Research Centre for Health Promotion and Wellbeing.

Jackson, Natalie. 2011. The Demographic Forces Shaping New Zealand's Future. What Population Aging [Really] Means. NIDEA Working Papers No 1 University of Waikato, National Institute of Demographic and Economic Analysis. 1-27. http://hdl.handle.net/10289/6539.

Kendall, Stephen, and Masao Ando. 2005. "Theory and Methods In Support of Adaptable Buildings." Paper presented at the 2005 World Sustainable Building Conference, Tokyo, September 27-29, 2005. 3017-3021. http://www.sb05.com/academic/10_IssuePaper.pdf.

Li, Wendy Wen. 2011. "Shifting Selves: Home Beyond the House-A Study of Aging, Housing and Wellbeing of Older Chinese Migrants to New Zealand." PhD diss., University of Waikato.

Lupis, Francelle, Russell McVeagh, and Craig McGarr. 2013. "Intensification Issues for Auckland's Aging Population.” Accessed 2013. http://www.russellmcveagh.com/Portals/1/Documents/Publication\%20PDFs/Intensification \%20issues\%20for\%20Aucklands\%20ageing\%20population_FZL_11Septebmer2013.pdf

Lutz, Wolfgang, Warren Sanderson, and Sergei Scherbov. "The Coming Acceleration of Global Population Aging." Nature 451(7179): 716-719. doi:10.1038/nature06516.

Malanowski, Norbert, Marcelino Cabrera, and Rukiye Özcivelek. 2008. Active Aging and Independent living Services the Role of Information and Communication Technology. Luxembourg: Office for Official Publications of the European Communities.

Martin, Linda G. 2010. "Demography and Aging." In Handbook of Aging and the Social Sciences, edited by Rober H. Binstock, Linda K. George, 33-45. London, UK: Academic Press.

McEwan, Ann. 1999. "Learning By Example: Architectural Education in New Zealand Before 1940." Fabrications 9(1): 1-16. Doi:10.1080/10331867.1999.10525118.

Ministry of Social Development. 2001. Positive Aging in New Zealand. Wellington: Ministry of Social Development.

Mohammed, Maryam. 2015. "The Housing Situation of Nigeria." Leadership, March 17. http://leadership.ng/features/418098/the-housing-situation-in-nigeria.

Mudiare, Patience Edirin Ukiri. 2013. "Abuse of the Aged in Nigeria: Elders Also Cry." American International Journal of Contemporary Research 3(9): 79-87.

Newman, Rachelle, and Catherine Bridge. 2011. "Universal and Adaptable Housing Design in Australia: Policy, Progress and Problems." Paper presented at the International Conference on Best Practices in Universal Design a part of the Festival of International Conferences on Caregiving, Disability, Aging and Technology-FICCDAT, Toronto, Ontario, June 5-8, 2010.

http://www.unsworks.unsw.edu.au/primo_library/libweb/action/dlDisplay.do?vid=UNSW ORKS\&docId=unsworks_9954.

Nugent, Sarah, Anna Packard, Erica Brabon, and Stephanie Vierra. 2011. "Living, Regenerative, and Adaptive Buildings." Whole Building Design Guide (WBDG), A program of the National Institute of Building Sciences. Accessed June 18, 2014. http://www.wbdg.org/resources/livingbuildings.php?r=select_professionals.

Olotuah, Abiodun O., and Olutunde S. Adesiji. 2005. "An Appraisal of Architectural Education in Nigeria." Paper presented at Built Environment Education Conference (CEBE), London, UK, September 5-6, 2005.

Olotuah, Abiodun O. 2009. "Demystifying the Nigerian Urban Housing Question." Inaugural Lecture Series 53 delivered at The Federal University of Technology, Akure Nigeria.

Olotuah, Abiodun O., and Aminat O. Ajenifujah. 2009. "Architectural Education and Housing Provision in Nigeria." CEBE Transactions, 6(1): 86-102. https://www.heacademy.ac.uk/sites/default/files/tran.6.1f.pdf. 
O’Sullivan, Fran. 2010. Elderly Population A Future Concern. The New Zealand Herald, September 10. Accessed September 2013. http://www.nzherald.co.nz/nz/news/article.cfm?c_id=1\&objectid=10672507.

Petroff, Alanna. 2014. "World Getting 'Super-aged' at Scary Speed." CNN Money. Last modified August 21, 2014. http://money.cnn.com/2014/08/21/news/economy/aging-countriesmoodys/index.html

Saville-smith, Kay. 2010. "It's Our Future and It's Not OK." Paper presented at the 2010 Australasian Housing Researchers' Conference (AHRC), Auckland New Zealand, November 17-19.

Saville-Smith, Kay, Bev James, Julie Warren, and Andrew Coleman. 2009. Older People's Housing Futures in 2050: Three Scenarios for an Aging Society. Centre for Housing Research, Aotearoa New Zealand.

Schmidt III, Robert, Toru Eguchi, Simon Austin, and Alistair Gibb. 2010. "What Is the Meaning of Adaptability in the Building Industry?" A paper presented at the 16th International Conference on Open and Sustainable Building, May17-19. Accessed July 14, 2014. http://adaptablefutures.com/wp-content/uploads/2011/11/Schmidt-et-al.-2010b.pdf.

Statistics New Zealand. 2000. Population Aging in New Zealand. Accessed August 20, 2014. http://www.stats.govt.nz/browse_for_stats/people_and_communities/older_people/popageing-in-nz.aspx

Togonu-Bickersteth, Funmi, and Akanni Ibukun Akinyemi. 2014. "Aging and National Development in Nigeria: Costly Assumptions and Challenges for the Future." African Population Studies 27(2s): 361-371.

Turner, John FC. 1977. Housing By People: Towards Autonomy in Building Environments. New York: Pantheon Books.

Whangarei District Council. 2015. Planning For Papakainga Housing. Accessed October 10, 2015. http://wdc.govt.nz/CommunitySafetyandSupport/Housing/Documents/Papakaingahousing-brochure.pdf

World Health Organization. 2002. Active Aging: A Policy Framework. Geneva, Switzerland: WHO Press. http://www.who.int/ageing/publications/active_ageing/en/.

World Health Organization. 2007. Global Age-friendly Cities: A Guide. World Health Organization. Geneva, Switzerland: WHO Press. http://www.who.int/ageing/publications/Global_age_friendly_cities_Guide_English.pdf

Yilmaz, Meltem. 2006 "Sustainable Design in Architecture." Paper presented in Design Society 36: DESIGN 2006, the 9th International Design Conference, Dubrovnik, Croatia, May 15-16. https://www.designsociety.org/publication/19157/sustainable_design_in_architecture.

\section{ABOUT THE AUTHORS}

Olufunto Ijatuyi: Olufunto is a PhD Student in the School of Architecture and Planning, Creative Arts and Industry, University of Auckland. His specific research is in the area of age-friendly housing within the built environment. Olufunto Ijatuyi graduated from the Federal University of Technology Akure, Nigeria, where he also had both teaching and research experience. His generic interests cover human settlement studies and the livability and sustainability of the built environment.

Errol Haarhoff: Errol is a Professor in the School of Architecture and Planning at the University of Auckland, New Zealand. His area of expertise includes urban design, architectural design, urban growth management, urban housing, urban settlement history, and urban design theory. He is a member of New Zealand Institute of Architects and International Planning History Society. He has won several awards in the area of research excellence and sustained teaching excellence.

Alessandro Melis: Alessandro teaches sustainable design; and His specialist teaching, supervisory and research interests are in the fields of climate design, radical theory and criticism, 
extreme architecture, sustainable urban strategies and conservation. He has been a guest professor in institutions such as die Angewandte Vienna, the Anhalt University Dessau, and the University of Sassari. He has been honorary fellow at the Edinburgh School of Architecture and lectured in Florence, Rome and Perugia amongst other cities. He has written several books, articles and essays published in Europe and USA. In 1996 he founded Heliopolis 21, an international firm based in Italy (Pisa) and Germany (Berlin).

\section{APPENDIX}

Table 5: List of 2015 courses at Arch-FUTA (Bachelors)

\begin{tabular}{|c|c|}
\hline Semester One & Semester Two \\
\hline \multicolumn{2}{|c|}{ Year One } \\
\hline $\begin{array}{l}\text { ARC 101, Graphic Communication I } \\
\text { (10 points) }\end{array}$ & ARC102, Graphic Communication II (10 points) \\
\hline $\begin{array}{l}\text { ARC 103, Freehand Sketching I (10 } \\
\text { points) }\end{array}$ & ARC 104, Freehand Sketching II (10 points) \\
\hline $\begin{array}{l}\text { ARC106, Art And Architectural } \\
\text { Appreciation (10 points) }\end{array}$ & IDD 108, Art Appreciation (10 points) \\
\hline $\begin{array}{l}\text { URP 103, Nature Of Environmental } \\
\text { Science (10 points) }\end{array}$ & $\begin{array}{l}\text { ARC105, Introduction To Architecture (15 } \\
\text { points) }\end{array}$ \\
\hline $\begin{array}{l}\text { MEE 101, Engineering Drawing I (15 } \\
\text { points) }\end{array}$ & MEE 102, Workshop Practice I (10 points) \\
\hline $\begin{array}{l}\text { IMT 101, Elementary Mathematics I (15 } \\
\text { points) }\end{array}$ & IMT 102, Elementary Mathematics II (15 points) \\
\hline PHY 101, General Physics I (15 points) & PHY 102, General Physics II (15 points) \\
\hline $\begin{array}{l}\text { PHY 107, General Physics (Laboratory) I } \\
\text { (5 points) }\end{array}$ & $\begin{array}{l}\text { PHY 108, General Physics (Laboratory) II (5 } \\
\text { points) }\end{array}$ \\
\hline GNS 101, Use Of English I (10 points) & $\begin{array}{l}\text { CSC 142, Introductory Computer Science (10 } \\
\text { points) }\end{array}$ \\
\hline GNS 103, Information Retrieval (5 points) & GNS 106, Logic and Philosophy (10 points) \\
\hline \multicolumn{2}{|c|}{ Year Two } \\
\hline $\begin{array}{l}\text { ARC 201, Architectural Design I, }(20 \\
\text { points) }\end{array}$ & ARC 201, Architectural Design II, (20 points) \\
\hline $\begin{array}{l}\text { ARC 203, Architectural Graphics I } \\
\text { (10 points) }\end{array}$ & ARC 204, Architectural Graphics II (10 points) \\
\hline $\begin{array}{l}\text { ARC 205, Basic Construction Method } \\
\text { (15 points) }\end{array}$ & $\begin{array}{l}\text { ARC 206, Building Components And Materials } \\
\text { (15 points) }\end{array}$ \\
\hline $\begin{array}{l}\text { ARC } 211, \text { Theory of Structures I (10 } \\
\text { points) }\end{array}$ & ARC 212, Theory of Structure II (10 points) \\
\hline QSV 205, Land Surveying I (10 points) & QSV 206, Land Surveying II (10 points) \\
\hline $\begin{array}{l}\text { CSC 241, Computer Programming I } \\
\text { (15 points) }\end{array}$ & ARC 210, Workshop Practice (Crafts) (10 points) \\
\hline $\begin{array}{l}\text { CSP 201, General Agriculture (Theory) } \\
\text { (5 points) }\end{array}$ & $\begin{array}{l}\text { CRP 210, General Agriculture (Practical) (10 } \\
\text { points) }\end{array}$ \\
\hline $\begin{array}{l}\text { GNS 201, Man and His Environment } \\
\text { (15 points) }\end{array}$ & GNS 202, Principles of Economics (15 points) \\
\hline $\begin{array}{l}\text { GNS 203, Nigerian History \& Culture } \\
\text { (15 points) }\end{array}$ & $\begin{array}{l}\text { ARC 208, Groundwork of Architectural History } \\
\text { (10 points) }\end{array}$ \\
\hline \multicolumn{2}{|c|}{ Year Three } \\
\hline ARC 301, Architectural Design III (25 & ARC 301, Architectural Design IV (25 points) \\
\hline
\end{tabular}




\begin{tabular}{|c|c|}
\hline points) & \\
\hline $\begin{array}{l}\text { ARC 303, Visual Design Workshop (10 } \\
\text { points) }\end{array}$ & $\begin{array}{l}\text { ARC 302, Building Components And Methods (15 } \\
\text { points) }\end{array}$ \\
\hline $\begin{array}{l}\text { ARC 305, Building Components and } \\
\text { Services (15 points) }\end{array}$ & $\begin{array}{l}\text { ARC 304, Building Structures (R.C. Designs) (15 } \\
\text { points) }\end{array}$ \\
\hline $\begin{array}{l}\text { ARC 307, History of Western Architecture } \\
\text { I(10 points })\end{array}$ & ARC 306, Village Survey (10 points) \\
\hline $\begin{array}{l}\text { 309, Environmental Control: Climate (10 } \\
\text { points) }\end{array}$ & $\begin{array}{l}\text { ARC } 308, \text { History of Western Architecture II (10 } \\
\text { points) }\end{array}$ \\
\hline $\begin{array}{l}\text { URP 409, Urban Renewal Process (10 } \\
\text { points) }\end{array}$ & ARC 310, Building Economics I (10 points) \\
\hline $\begin{array}{l}\text { URP 201, Basic Elements of Planning (10 } \\
\text { points) }\end{array}$ & URP 310, Urban Design Theory (15 points) \\
\hline $\begin{array}{l}\text { QSV 201, Principles Of Measurement And } \\
\text { Description I (15 points) }\end{array}$ & \\
\hline \multicolumn{2}{|c|}{ Year Four } \\
\hline $\begin{array}{l}\text { ARC 401, Architectural Design V } \\
\text { (30 points) }\end{array}$ & $\begin{array}{l}\text { ARC 402, Industrial Based Supervisors' } \\
\text { Assessment ( } 20 \text { points) }\end{array}$ \\
\hline $\begin{array}{l}\text { ARC 403, Landscape Theory and Design } \\
\text { (10 points) }\end{array}$ & $\begin{array}{l}\text { ARC 404, FUTA Supervisor's Assessment } \\
\text { (20 points) }\end{array}$ \\
\hline $\begin{array}{l}\text { ARC 405, Construction Detailing I } \\
\text { (15 points) }\end{array}$ & $\begin{array}{l}\text { ARC 406, Students' Report \& Practical } \\
\text { Presentation ( } 20 \text { points) }\end{array}$ \\
\hline $\begin{array}{l}\text { ARC 407, Modern Movement In Arch I } \\
\text { (10 points) }\end{array}$ & \\
\hline $\begin{array}{l}\text { ARC 409, Environmental Control II } \\
\text { (Lighting \& Illumination) (10 points) }\end{array}$ & \\
\hline $\begin{array}{l}\text { ARC 411, Building Structures } \\
\text { (Steel/Timber) Design (15 points) }\end{array}$ & \\
\hline $\begin{array}{l}\text { ARC 413, Behavioral Architecture } \\
\text { (10 points) }\end{array}$ & \\
\hline $\begin{array}{l}\text { QSV 403, Construction Economics } \\
\text { (15 points) }\end{array}$ & \\
\hline \multicolumn{2}{|r|}{ Year Five } \\
\hline $\begin{array}{l}\text { ARC 501, Advanced Design Studio I } \\
\text { (30 points) }\end{array}$ & ARC 501, Advanced Design Studio II (30 points) \\
\hline $\begin{array}{l}\text { ARC 503, Construction Detailing II } \\
\text { (15 points) }\end{array}$ & $\begin{array}{l}\text { ARC 504, Comparative Studies Of Built Form } \\
\text { (10 points) }\end{array}$ \\
\hline $\begin{array}{l}\text { ARC 505, Modern Movements In } \\
\text { Architecture II (10 points) }\end{array}$ & ARC 506, Interior Design (10 points) \\
\hline $\begin{array}{l}\text { ARC 507, Environmental Control III } \\
\text { (Acoustics And Noise Control) (10 points) }\end{array}$ & ARC 508, Housing Seminar (10 points) \\
\hline $\begin{array}{l}\text { ARC 599, Independent Research Project I } \\
\text { (15 points) }\end{array}$ & $\begin{array}{l}\text { ARC 599, Independent Research Project II (15 } \\
\text { points) }\end{array}$ \\
\hline $\begin{array}{l}\text { URP 311, Rural Development And } \\
\text { Planning (10 points) }\end{array}$ & ARC 510, Building Law (10 points) \\
\hline $\begin{array}{l}\text { ARC 511, Tourism And Recreation } \\
\text { Planning (10 points) }\end{array}$ & \\
\hline
\end{tabular}

Source: http://arc.futa.edu.ng/courselist.php

Table 6: Complete list of 2015 courses at Arch-FUTA (Masters)

\begin{tabular}{|l|l|l|}
\hline \multicolumn{1}{|c|}{} & \multicolumn{1}{|c|}{ Semester One } & Semester Two \\
\hline \multicolumn{2}{|c|}{ Year 1} \\
\hline $\begin{array}{l}\text { ARC 801, Advanced architectural design (30 } \\
\text { points) }\end{array}$ & Arc 804 arbitration and awards (15 points) \\
\hline
\end{tabular}




\begin{tabular}{|c|c|}
\hline ARC 803, specification writing (15 points) & $\begin{array}{l}\text { Arc } 806 \text { Design economics and cost planning } \\
\text { (15 points) }\end{array}$ \\
\hline Arc 805 research methodology (10 points) & $\begin{array}{l}\text { Arc } 808 \text { professional practice and procedure } \\
\text { II (15 points) }\end{array}$ \\
\hline $\begin{array}{l}\text { Arc } 807 \text { professional practise and procedure } \\
\text { I(15 points) }\end{array}$ & Arc 810 applied climatology (15 points) \\
\hline Arc 809 advanced urban design (10 points) & \\
\hline $\begin{array}{l}\text { Arc } 811 \text { environmental impact assessment } \\
\text { (15 points) }\end{array}$ & \\
\hline $\begin{array}{l}\text { Arc } 813 \text { construction management } \\
\text { points) }\end{array}$ & \\
\hline \multicolumn{2}{|l|}{ Year 2} \\
\hline Arc 812 design seminar (20 points) & \\
\hline Arc 814 current issues in practice (20 points) & \\
\hline $\begin{array}{l}\text { Arc } 899 \text { advanced design studio: thesis II ( } 80 \\
\text { points) }\end{array}$ & \\
\hline
\end{tabular}

Table 7: List of 2015 courses at Arch-CAI (Bachelors)

\begin{tabular}{|c|c|c|}
\hline & Semester One & Semester Two \\
\hline \multicolumn{3}{|c|}{ Year One } \\
\hline 1 & ARCHDES 100 - Design 1 (20 points) & ARCHDES 101 - Design 2 (20 points) \\
\hline 2 & $\begin{array}{l}\text { ARCHDRC } 102 \text { - Architectural Media I (10 } \\
\text { points) }\end{array}$ & $\begin{array}{l}\text { ARCHHTC } 102 \text { - Modern Architecture and } \\
\text { Urbanism (15 points) }\end{array}$ \\
\hline 3 & $\begin{array}{l}\text { ARCHTECH } 106 \text { - Architecture and } \\
\text { Sustainability (15 points) }\end{array}$ & $\begin{array}{l}\text { ARCHTECH } 107 \text { - Design Technology I (10 } \\
\text { points) }\end{array}$ \\
\hline 4 & General Education course (15 points) & General Education course (15 points) \\
\hline \multicolumn{3}{|c|}{ Year Two } \\
\hline 5 & ARCHDES 200 - Design 3 (30 points) & ARCHDES 201 - Design 4 (30 points) \\
\hline 6 & $\begin{array}{l}\text { ARCHDRC } 202 \text { - Architectural Media II (10 } \\
\text { points) }\end{array}$ & $\begin{array}{l}\text { ARCHHTC } 236 \text { - Introduction to Architectural } \\
\text { Theory (10 points) }\end{array}$ \\
\hline 7 & $\begin{array}{l}\text { ARCHHTC } 235 \text { - Contemporary Architecture } \\
\text { and Urbanism (10 points) }\end{array}$ & $\begin{array}{l}\text { ARCHTECH } 208 \text { - Environmental Design I (15 } \\
\text { points) }\end{array}$ \\
\hline 8 & $\begin{array}{l}\text { ARCHTECH } 207 \text { - Design Technology II (15 } \\
\text { points) }\end{array}$ & \\
\hline \multicolumn{3}{|c|}{ Year Three } \\
\hline 9 & ARCHDES 300 - Design 5 (30 points) & ARCHDES 301 - Design 6 (30 points) \\
\hline 10 & $\begin{array}{l}\text { ARCHHTC } 340 \text { - Oceanic Architecture and } \\
\text { Urbanism (10 points) }\end{array}$ & $\begin{array}{l}\text { ARCHHTC } 339 \text { - Pre-modern Architecture and } \\
\text { Urbanism (10 points) }\end{array}$ \\
\hline 11 & $\begin{array}{l}\text { ARCHTECH } 307 \text { - Environmental Design II (10 } \\
\text { points) }\end{array}$ & $\begin{array}{l}\text { ARCHTECH } 312 \text { - Design Technology III (10 } \\
\text { points) }\end{array}$ \\
\hline 12 & $\begin{array}{l}\text { And One elective taken from ARCHDRC } 300- \\
304,370-373 \text { ( } 10 \text { points })\end{array}$ & ARCHGEN 300 - Design as Research (10 points) \\
\hline
\end{tabular}

Source: http://www.creative.auckland.ac.nz/en/for/current-students/cs-course-planning-andenrolment.html\#par_contentblock_2_O

Table 8: List of 2015 courses at Arch-CAI (Masters)

Year 1 Core Courses

\begin{tabular}{|l|l|l|l|}
\hline \multirow{2}{*}{ ARCHDES 700} & Advanced Design 1 & S1 & 30 points \\
\hline
\end{tabular}




\begin{tabular}{|c|c|c|c|}
\hline ARCHDES 701 & Advanced Design 2 & $S 2$ & 30 points \\
\hline ARCHPRM 700 & Professional Studies 1 & $S 1$ & 15 points \\
\hline ARCHPRM 701 & Professional Studies 2 & $S 2$ & 15 points \\
\hline \multicolumn{4}{|c|}{$\begin{array}{l}\text { Elective courses-30 points from courses listed below or 15points fror } \\
\text { level courses offered at this University, approved by the Head of Schor } \\
\text { Architecture and Planning. } \\
\text { Note: Each 15-point elective must be from two different subject areas. }\end{array}$} \\
\hline ARCHGEN 712 & Special Topic in History, Theory and Criticism 2 (Building the case) & $S 2$ & 15 points \\
\hline ARCHGEN 713 & Special Topic in History, Theory and Criticism 3 (Heritage Conservation) & $S 1$ & 15 points \\
\hline ARCHGEN 714 & Special Topic in History, Theory and Criticism 4 (Looking Again) & $S 1$ & 15 points \\
\hline ARCHGEN 715 & Special Topic in History, Theory and Criticism 5 (Surfaces in situ) & $S 2$ & 15 points \\
\hline ARCHGEN 721 & Special Topic in Sustainable Design 1 (Designing with Resilience Thinking) & $S 2$ & 15 points \\
\hline ARCHGEN 724 & $\begin{array}{l}\text { Special Topic in Sustainable Design } 4 \text { (Climate Sensitive Design for urban } \\
\text { mutations) }\end{array}$ & $S 1$ & 15 points \\
\hline ARCHGEN 731 & Special Topic in Urban Design 1 (Cities within the City) & $S 2$ & 15 points \\
\hline ARCHGEN 733 & Special Topic in Urban Design 3 (Urban Public Spaces in the Contemporary City) & S1 & 15 points \\
\hline ARCHGEN 734 & Special Topic in Urban Design 4 (Dissenting Images and unbuilt urban projects) & $S 2$ & 15 points \\
\hline URBDES 702 & Urban Design Theory and Practice & S1 & 15 points \\
\hline ARCHGEN 741 & SpecialTopic in Materials and Fabrication 1 (Timber Workshop Project) & S1 & 15 points \\
\hline ARCHGEN 742 & Special Topic in Materials and Fabrication 2 (Timber Technology) & $S 2$ & 15 points \\
\hline ARCHGEN 743 & SpecialTopic in Materials and Fabrication 3 (Disruptive Technologies) & $S 2$ & 15 points \\
\hline ARCHGEN 744 & Special Topic in Materials and Fabrication 4 (Advanced Sound and Buildings) & $S 1$ & 15 points \\
\hline ARCHGEN 745 & $\begin{array}{l}\text { Special Topic in Materials and Fabrication } 5 \\
\text { (Light Scale II: AR Installation and Research Project) }\end{array}$ & $S 1$ & 15 points \\
\hline
\end{tabular}

\section{Year 2 core courses}

\begin{tabular}{|l|l|l|l|}
\hline ARCHDES 796A & Thesis & S1 & 60 points \\
\hline ARCHDES 796B & Thesis & S2 & 60 points \\
\hline & & total & 240 \\
noints
\end{tabular}

Source: http://www.creative.auckland.ac.nz/en/for/current-students/cs-course-planning-andenrolment.html\#par_contentblock_2_O 